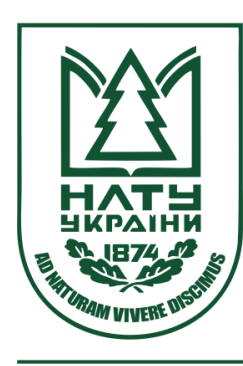

Науковий вісник НЛТУ України Scientific Bulletin of UNFU

https://nv.nltu.edu.ua

https://doi.org/10.36930/40300122

$@ \bowtie$ Correspondence author

Article received 30.01.2020 p.

Article accepted 27.02.2020 p.

B. O. Korchak

UDK 665.[6+664]

kor4ak93@gmail.com

Б. О. Корчак, О. Б. Гринишин, Т. І. Червінський, Н. М. Витрикуш, А. О. Нагурський, Р. В. Іващенко

Начіональний університет "Львівська політехніка", м. Львів, Україна

\title{
ОЧИЩЕННЯ ВІДПРАЦЬОВАНИХ МІНЕРАЛЬНИХ МОТОРНИХ ОЛИВ КРИСТАЛІЧНИМ КАРБАМІДОМ
}

Під час експлуатації автотранспортного засобу мінеральна моторна олива у двигуні внутрішнього згорання (ДВ3) піддається безперервному впливу високої температури, окиснення, термічного розкладу, зовнішніх забруднювачів, каталізаторів (продуктів зношення металевих поверхонь) тощо. Внаслідок цього в ній накопичуються продукти зношення деталей ДВ3 та розкладу присадок, продукти окиснення вуглеводневої частини, асфальто-смолисті речовини тощо, що спричиняє незворотні зміни ії якісного хімічного складу. Для видалення з відпрацьованих олив оксигеновмісних продуктів старіння та зниження їхнього кислотного числа доцільно використовувати метод коагуляції. Одним з легкодоступних та перспективних коагулянтів для очищення відпрацьованих мінеральних моторних олив може слугувати кристалічний карбамід. Його додавали до відпрацьованих олив і перемішували за підвищеної температури. Контроль ефективності процесу очищення карбамідом здійснено за кислотним числом оливи. Використаний карбамід разом із виокремленими компонентами оливи відділяли фільтруванням. Встановлено оптимальні умови процесу, а саме: кількість карбаміду - 5 \% мас. на сировину; температуpa $-140{ }^{\circ} \mathrm{C}$; тривалість перемішування - 80 хв. Для вивчення зміни експлуатаційних властивостей очищених мінеральних моторних олив здійснено дослідження за стандартизованими методиками та за допомогою рентгенофлуоресцентного та ІЧспектрального методів аналізів. Встановлено, що внаслідок очищення відпрацьованих олив карбамідом їхнє кислотне число істотно зменшується, що підтверджується ІЧ-спектральним аналізом. Відбувається також незначне підвищення індексу в'язкості олив, а також зниження вмісту механічних домішок, води. Зольність олив також зменшується. Це підтверджено також результатами рентгенофлуоресцентного аналізу. Використання кристалічного карбаміду для очищення ВММО дає змогу зменшити вміст оксигеновмісних продуктів старіння, водночас, в очищеній оливі залишаються небажані поліциклічні ароматичні вуглеводні, асфальто-смолисті речовини, продукти розкладу присадок та механічні домішки, для видалення яких необхідно використовувати додаткові стадії очищення.

Ключові слова: відновлення олив; ІЧ-спектроскопія; рентгенофлуоресцентний аналіз; коагуляція; кислотне число.

Вступ. Відпрацьовані мінеральні моторні оливи (ВММО) - це токсичні, складні багатокомпонентні системи, які утворюються у процесі експлуатації двигуна внутрішнього згорання. У ВММО ідентифіковано понад 140 видів канцерогенних поліциклічних вуглеводнів. Кількість цих сполук у ВММО збільшується прямо пропорційно до зростання тривалості ії експлуатації [3, 21]. Саме тому ВММО віднесені до категорії небезпечних відходів, а за токсичністю їх відносять до 4-го класу. В Україні та світі діють рішення Стокгольмської та Базельської конвенцій [12], згідно з якими потрібно контролювати утворення та утилізацію відпрацьованих олив (ВО).

Сьогодні Україна споживає понад 1 млн т/рік свіжих олив, водночас, офіційно збирає близько 500 тис. т/рік відпрацьованих нафтопродуктів. В Україні щорічно накопичуються чималі об'єми ВММО, поводження 3 якими $\epsilon$ однією 3 найактуальніших екологічних проблем, через недостатньо розвинену систему збору та майже не розвинуті потужності з їхньої регенерації [15].

Внаслідок експлуатації автотранспортного засобу мінеральна моторна олива у двигуні піддається безперервному впливу високих температур, окиснення, терморозкладу, зовнішніх забрудників, каталізаторів (продуктів зносу металевих поверхонь) тощо [20]. Внаслідок цього в ній накопичуються продукти розкладу присадок та зношення деталей ДВЗ, продукти окиснення вуглеводневої частини, асфальто-смолисті речовини, залишки неповноти згорання палива, що спричиняє незворотні зміни їі якісного хімічного складу.

Інформація про авторів:

Корчак Богдан Орестович, канд. техн. наук, асистент, кафедра цивільної безпеки. Email: kor4ak93@gmail.com

Гринишин Олег Богданович, д-р техн. наук, професор, кафедра хімічної технології переробки нафти і газу.

Email: ogrynyshyn@ukr.net

Червінський Тарас Ігорович, канд. хім. наук, доцент, кафедра хімічної технології переробки нафти і газу.

Email: chervinskijt@gmail.com

Витрикуш Наталія Миронівна, канд. техн. наук, доцент, кафедра цивільної безпеки. Email: nvytrykush@ukr.net

Нагурський Андрій Олегович, канд. техн. наук, асистент кафедра хімічної інженерії. Email: nagurskiy@ukr.net

Іващенко Руслана Вадимівна, студент, кафедра хімічної технології переробки нафти і газу.

Email: rusyaivashchenko21@gmail.com

Цитування за ДСтУ: Корчак Б. О., Гринишин О. Б., Червінський Т. І., Витрикуш Н. М., Нагурський А. О., Іващенко Р. В. Очищення відпрацьованих мінеральних моторних олив кристалічним карбамідом. Науковий вісник НлТУ України. 2020, т. 30, № 1. С. 127-131.

Citation APA: Korchak, B. O., Hrynyshyn, O. B., Chervinskyy, T. I., Vytrykush, N. M., Nagurskyy, A. O., \& Ivashchenko, R. V.

(2020). Purification of the used mineral engine oils by crystalline carbamide. Scientific Bulletin of UNFU, 30(1), 127-131.

https://doi.org/10.36930/40300122

Науковий вісник НЛтУ України, 2020, т. 30, № 1

Scientific Bulletin of UNFU, 2020, vol. 30, no 1 
Значне використання для регенерації ВО отримали процеси коагуляції з використанням різноманітних коагулянтів. Сьогодні нарівні з відомими процесами коагуляції ВО варті уваги методи з використанням розчинів карбаміду. Процес коагуляції ВО передбачає змішування нагрітої до робочої температури ВО з певною кількістю водного розчину карбаміду [17] або водного розчину карбаміду, моноетиламіну та алюмінію хлорид [1] упродовж певного проміжку часу. За таких умов активно починаються процеси коагуляції і седиментації частинок дисперсної фази. Нижче розглянемо їх докладніше.

Аналіз літературних джерел. Відомий спосіб очищення ВММО змішуванням попередньо нагрітої до 80$100{ }^{\circ} \mathrm{C}$ ВMМО з 30-50 \%-м водним розчином карбаміду, взятого в кількості 1,0\% мас. від маси ВММО, 3 подальшим центрифугуванням очищеної оливи й вилученням забруднень [5].

Автори [23] запропонували спосіб очищення ВО внаслідок попереднього нагрівання оливи й змішування з 30-50 \%-м водним розчином карбаміду, взятого в кількості 0,5-1,0 \% у розрахунку на сухий карбамід від маси ВО. Відпрацьовану оливу нагрівають до $70-75^{\circ} \mathrm{C}$ та після додавання розчину карбаміду в оливу додають 22,5 \% етилового спирту. За встановленої температури оливу витримують упродовж години постійно перемішуючи, після чого вилучають забруднення центрифугуванням. На відміну від [5, 23], автори [18] запропонували спосіб очищення ВО від продуктів старіння і забруднень внаслідок змішування попередньо нагрітої оливи та $0,05-0,1 \% 40 \%$-го аміачного розчину карбаміду в розрахунку на об'єм ВО й подальшим розділенням оливи від забруднень у центрифузі двигуна внутрішнього згорання. Однак, недоліком цих способів є використання водних або спиртових розчинів карбаміду, які внаслідок змішування з нафтовою оливою здатні утворювати стійку водо-оливну емульсію, сприяють піноутворенню, що негативно впливає на експлуатаційні властивості очищеної оливи.

У нафтопереробній промисловості карбамід переважно використовують у процесах депарафінізації дизельних фракцій з метою видалення з них парафінових вуглеводнів. Варто зазначити, що цей процес характеризується використанням значних кількостей карбаміду $\sim 100 \%$ мас. на сировину, розчинника 50-100 \% мас. на сировину, тривалістю процесу 30 хв та температурою процесу $30-50{ }^{\circ} \mathrm{C}$. Внаслідок процесу утворюються комплекси карбаміду з парафіновими вуглеводнями, видалення яких відбувається за допомогою фільтрації, а одержаний деперафінізат характеризується вагомим зниженням значень температури застигання та незначним зменшенням значень кислотного числа.

Раніше у роботі [2] автори встановили можливість очищення суміші відпрацьованих мінеральних моторних олив у присутності карбаміду та визначили зміну експлуатаційних характеристик очищених олив, однак одержаних результатів недостатньо для підтвердження доцільності використання цього методу.

Отже, важливо створити новий спосіб очищення BMМО, який би характеризувався відсутністю використання розчинів (спиртових, водних, аміачних) карбаміду та забезпечив очищувані оливи нижчим значенням кислотного числа, відсутністю води та кращим значенням в'язкісно-температурних властивостей.
Об'єкт дослідження - відпрацьовані мінеральні моторні оливи марок М-10ДМ та NORMAL 15W40, експлуатаційні властивості яких було вивчено раніше у роботах $[10,13]$.

Предмет дослідження - методи і засоби очищення відпрацьованих мінеральних моторних олив кристалічним карбамідом.

Очищення ВММО карбамідом проводили на лабораторній установці, яку навели на рис. 1. У ємність, обладнану механічним перемішуванням, термометром та дозатором для подачі реагенту, завантажують ВММО, після чого її нагрівають до температури процесу та після іiі досягнення через дозатор під час безперервного перемішування додають кристалічний карбамід через певні однакові проміжки часу рівними порціями.

Після додавання останньої порції карбаміду процес здійснюють за раніше встановленої температури та тривалості. Після завершення процесу реакційну суміш охолоджують і переносять у ділильну воронку для відстоювання, після чого нижній шар осаду вилучають, а верхній шар очищеної оливи подають на фільтрування.

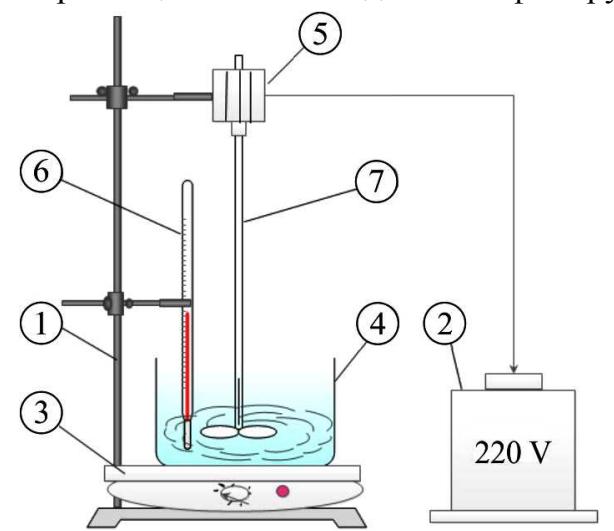

Рис. 1. Лабораторна установка для очищення ВММО карбамідом: 1) штатив; 2) блок живлення; 3) електронагрівач; 4) ємність; 5) електродвигун; 6) термометр; 7) перемішувальний пристрій

Рентгенофлуоресцентний спектральний аналіз для визначення елементного складу олив здійснювали на прецизійному аналізаторі Elvax Light SDD, призначення якого - визначення масової частки хімічних елементів в однорідних монолітних та порошкоподібних об'єктах. Для виконання аналізу підготували зразки оливи, які були спалені за температури $450{ }^{\circ} \mathrm{C}$ протягом 4 год, охолоджені в ексикаторі та перетерті в порошок [16]. ІЧ-спектроскопічні дослідження вихідної й відпрацьованої олив здійснювали на приладі Spectrum Two FT-IR spectrometer фiрми PerkinElmer у кюветі з селеніду цинку товщиною 0,1036 мм. Використовували програму Spectrum v.10.03.06.

Мета роботи та завдання дослідження. Встановити можливість використання кристалічного карбаміду та розробити метод очищення відпрацьованих мінеральних моторних олив у присутності кристалічного карбаміду від оксигеновмісних продуктів старіння, який би характеризувався відсутністю використання розчинів (спиртових, водних, аміачних) карбаміду та забезпечив очищувані оливи нижчим значенням кислотного числа, відсутністю води та кращим значенням в'язкісно-температурних властивостей.

Наукова новизна дослідження та практична значущість отриманих результатів. Встановлено доцільність використання кристалічного карбаміду для очи- 
щення ВММО з метою зменшення кислотного числа Доведено, що під час очищення ВММО кристалічним карбамідом не утворюється оливна емульсія, яка негативно впливає на експлуатаційні властивості оливи, на відміну від водних (спиртових) розчинів карбаміду.

Основний ефект від використання карбаміду для очищення ВММО такий:

- збільшення кінематичної в'язкості олив на 0,49-7,34 \%;

- збільшення індексу в'язкості (IB) олив на 2,27-5,45 \%;

- зниження кислотного числа (КЧ) олив на 71,42-88,19\%;

- зменшення вмісту механічних домішок на 28,20-37,10 \%;

- зниження зольності олив на $18,61-19,85 \%$.

Результати дослідження. Унікальною особливістю карбаміду є його здатність утворювати карбамідні комплекси гексагональної структури. Саме це зумовлює його здатність утворювати комплекси з н-алканами, органічними кислотами, кетонами, альдегідами, естерами за рахунок їх проникнення у порожнисті канали карбамідного комплексу. Одержані комплекси, так звані клатрати, утворення яких зумовлене тим, що нормальні алкани і їхні похідні проникають у найтонші порожнисті канали, наявні в кристалічній решітці карбаміду. Водночас, сполуки з розгалуженим вуглеводневим ланцюгом не утворюють комплексів 3 карбамідом, оскільки їхні молекули не можуть поміститися в каналах кристалічної решітки карбаміду [19].

Водночас, відомо [14, 19], що карбамід здатен адсорбувати на своїй поверхні високомолекулярні забруднення та осаджувати їх, внаслідок чого можливе їхне вилучення з ВО за допомогою стадії фільтрації. Осад, що залишився на фільтрі, є сумішшю карбаміду з компонентами оливи, подається на розділення фізичними методами. Після чого відокремлений карбамід осушується і повторно використовується у процесі очищення, а відділені компоненти можуть бути компонентом сировини для виробництва бітумів.

На ефективність процесу коагуляції впливає кількість введеного коагулянту, тривалість його контакту 3 відпрацьованою оливою та температура коагуляції (рис. 2). Як видно з цього рисунку, із підвищенням тривалості процесу очищення кристалічним карбамідом відбувається незначне його перетворення в біурет, через що необхідно підібрати параметри керування процесом так, щоб якомога зменшити втрати кристалічного карбаміду. Саме тому для розроблення методу очищення ВММО у присутності карбаміду необхідно було вивчити вплив чинників керування процесом: оптимальну кількість реагенту, встановити вплив температури та тривалості очищення ВО у присутності карбаміду.

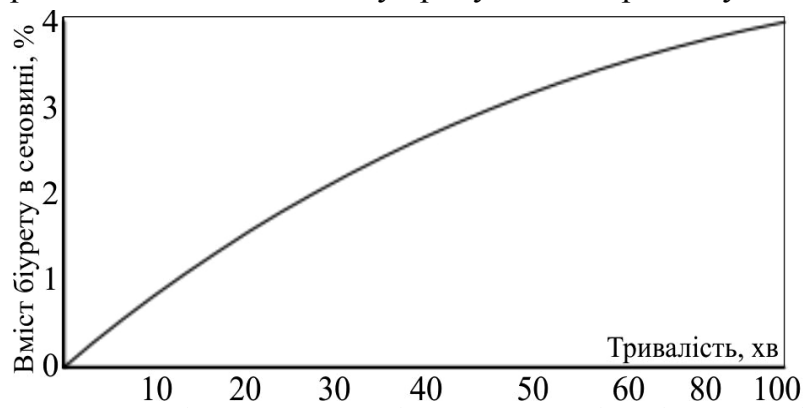

Рис. 2. Швидкість утворення біурету з карбаміду під час нагрівання за температури $160{ }^{\circ} \mathrm{C}$

Обговорення отриманих результатів. Як зазначалось вище, раніше у роботі [2] було встановлено можливість очищення суміші відпрацьованих мінеральних моторних олив у присутності карбаміду та встановлено зміну експлуатаційних характеристик очищених олив, однак одержаних результатів недостатньо для підтвердження доцільності використання цього методу.

За встановлених оптимальних умов процесу очищення ВММО у присутності карбаміду [2] (температура процесу $-140{ }^{\circ} \mathrm{C}$, тривалість - 80 хв, кількість реагенту $-5 \%$ мас. у розрахунку від кількості, взятої BO) здійснено очищення BMMO марок M-10ДМ та NORMAL 15W40. Результати подано в таблиці.

Таблиця. Експлуатаційні властивості очищених у присутності карбаміду мінеральних моторних олив марок М10ДМ Ta NORMAL $15 \mathrm{~W} 40$

\begin{tabular}{|c|c|c|c|c|}
\hline \multirow{2}{*}{ Показник } & \multicolumn{2}{|c|}{ М-10ДМ } & \multicolumn{2}{|c|}{ NORMAL 15W40 } \\
\cline { 2 - 5 } & $\begin{array}{c}\text { відрацьо- } \\
\text { вана }\end{array}$ & очищена & $\begin{array}{c}\text { відпрацьо- } \\
\text { вана }\end{array}$ & очищена \\
\hline $\begin{array}{c}\text { Кислотне чис- } \\
\text { ло, мг КОН/г }\end{array}$ & 2,71 & 0,32 & 1,96 & 0,56 \\
\hline Вміст води, \% & 0,14 & сліди & 0,15 & сліди \\
\hline $\begin{array}{c}\text { В'язкість, мм } / \mathrm{c} \\
v_{50} \\
v_{100}\end{array}$ & $\begin{array}{c}51,65 \\
10,22\end{array}$ & $\begin{array}{c}52,60 \\
10,97\end{array}$ & $\begin{array}{c}69,81 \\
13,96\end{array}$ & $\begin{array}{c}70,15 \\
14.54\end{array}$ \\
\hline Індекс в'язкості & 88 & 94 & 110 & 116 \\
\hline Зольність, \% & 0,940 & 0,765 & 0,534 & 0,428 \\
\hline $\begin{array}{c}\text { Вміст механіч- } \\
\text { них домішок, \% }\end{array}$ & 0,062 & 0,039 & 0,039 & 0,028 \\
\hline Вихід, \% мас. & - & 97,00 & - & 97,00 \\
\hline
\end{tabular}

Аналіз фізико-хімічних властивостей об'єктів досліджень здійснювали за стандартизованими методиками:

- визначення в'язкості згідно з даними [8];

- визначення вмісту води згідно $з$ даними [7];

- визначення зольності згідно з даними [4];

- визначення кислотного числа згідно з даними [9];

- визначення механічних домішок згідно з даними [6].

3 результатів, поданих у таблиці, можемо відзначити зміну в експлуатаційних властивостях очищеної в присутності карбаміду оливи NORMAL 15W40, а саме відбулось зменшення значень КЧ, вмісту води, механічних домішок та зольності. Водночас, відбувається незначне збільшення значень кінематичної в'язкості та IB. Одержані результати свідчать про доцільність використання кристалічного карбаміду в процесі очищення ВММО від кисневмісних продуктів старіння.

Методика процесу очищення ВММО у присутності карбаміду передбачає стадію фільтрування очищеної оливи від утвореного осаду. Тому рентгенофлуоресцентним аналізом вивчили зміну елементного складу очищених у присутності карбаміду олив марок М-10ДМ та NORMAL 15W40. Результати аналізу навели на рис. 3.

Як бачимо 3 результатів виконаних досліджень, в очищених у присутності карбаміду оливах М-10ДМ та NORMAL 15W40 спостерігаємо зменшення вмісту елементів неорганічної частини. Очевидно, що частина хімічних елементів, що входять до складу відпрацьованих олив, відокремлюються разом з осадом під час стадії фільтрування. Для підтвердження зміни кількості кисневмісних продуктів в очищеній карбамідом оливі М-10ДМ виконали ІЧ-спектральний аналіз відпрацьованої та очищеної оливи. Результати аналізу навели на рис. 4 та 5.

Застосуванням ІЧ-спектроскопії для аналізу мінеральних моторних олив здійснювали контроль якості оливи, визначали ступінь іï окиснення, вміст присадок тощо. ІЧ-спектроскопія в поєднанні з структурно-груповим аналізом вуглеводневої частини оливи дає змогу охарактеризувати склад мінеральних олив. 

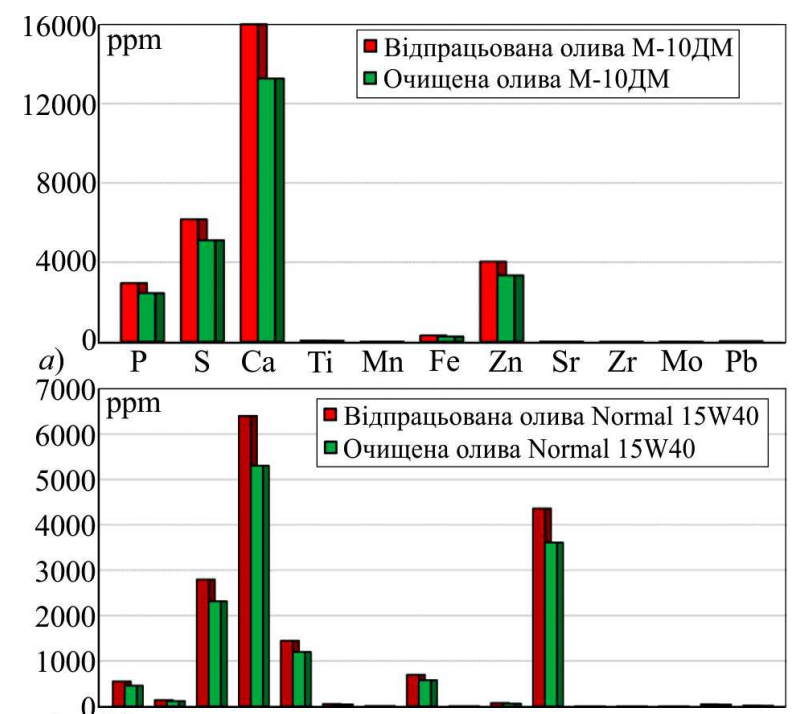

б) $\mathrm{Mg} \mathrm{Si}$ P S Ca Cr Mn Fe Ni Cu Zn As Rb Sr Mo Pb

Рис. 3. Зміна елементного складу відпрацьованих та очищених у присутності карбаміду олив марок M-10ДМ (A) та NORMAL 15W40 (Б)

Цей метод рекомендували для моніторингу процесу очищення/регенерації моторної оливи, способом порівняння ІЧ-спектрів відпрацьованої оливи та очищеної/регенерованої оливи, однієї і тієї ж марки [11]. Тобто за наявності одних і тих же піків для органічних сполук на ІЧ-спектрах водночас, відбувається зменшення інтенсивності смуг поглинання для цих сполук, що свідчить про зменшення їх кількості в очищеній оливі.

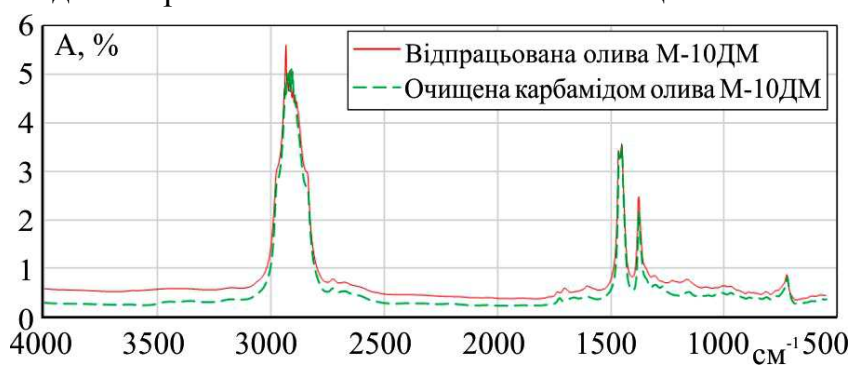

Рис. 4. ІЧ-спектри відпрацьованої та очищеної в присутності карбаміду мінеральної моторної оливи М-10ДМ

Як видно з рис. 4, ІЧ-спектри відпрацьованої та очищеної олив відрізняються зміною інтенсивності смуг поглинання вуглеводнів оливи. Парафіно-нафтенові вуглеводні в ІЧ-спектрах досліджуваних олив були ідентифіковані валентними коливаннями за 2935 $2915 \mathrm{~cm}^{-1}$, а також деформаційними коливаннями СНгрупи за 1470-1445 см-1 та валентними коливаннями СС групи в області 1740-1720 $\mathrm{cm}^{-1}$. Присутність ароматичних вуглеводнів в оливах була підтверджена інтенсивною смугою поглинання деформаційних коливань $\mathrm{CH}$ групи за $860 \mathrm{~cm}^{-1}$. Окрім цього, скелетні коливання C-C зв'язку ароматичного ядра були виявлені смугами поглинання в області 1610-1600 $\mathrm{cm}^{-1}$ [22].

ІЧ-спектральним аналізом ідентифіковано у відпрацьованій та очищеній оливах спирти, альдегіди, кетони, органічні кислоти тощо, що є продуктами іiї старіння. Їхня присутність в ІЧ-спектрах підтверджена зміною інтенсивності смуг поглинання валентних коливань $\mathrm{C}=\mathrm{O}$ в області $1740-1690 \mathrm{~cm}^{-1}$, а також валентними коливаннями за 1820-1740 $\mathrm{cm}^{-1}$ та асиметричними валентними коливаннями С-О зв'язку в області 1260$1150 \mathrm{~cm}^{-1}$ (див. рис. 5).

Суть очищення ВО карбамідом, на нашу думку, полягає в тому, що він виступає як коагулянт. Він зв'язує основну частину сполук кислого характеру, а також механічні домішки, воду та незначну частину неорганічних компонентів ВО, які надалі відокремлюються за допомогою фільтрування.

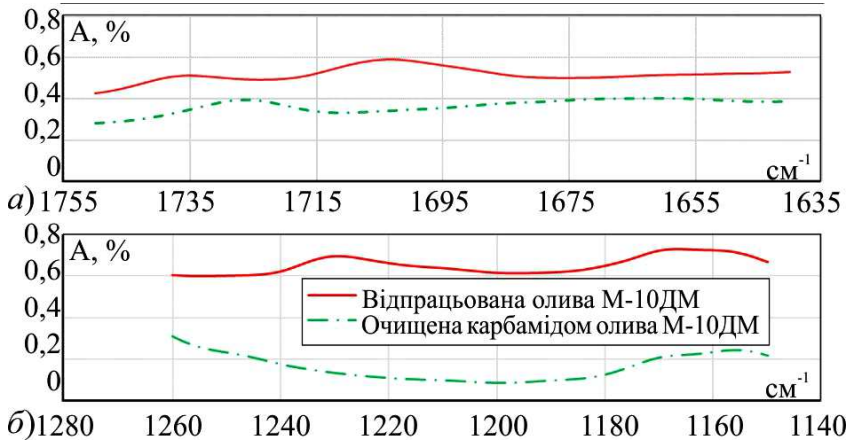

Рис. 5. Зміна інтенсивності смуг поглинання карбонових кислот (а) та їх похідних (б)

Як бачимо з рис. 5, в очищеній у присутності карбаміду оливі відбувається зміна інтенсивності смуг поглинання органічних кислот та їхніх похідних, що свідчить про можливість використання карбаміду з метою зменшення вмісту кисневмісних продуктів старіння ВО. Схожі закономірності спостерігаємо внаслідок очищення у присутності карбаміду BMMO NORMAL 15W40 (рис. 6).

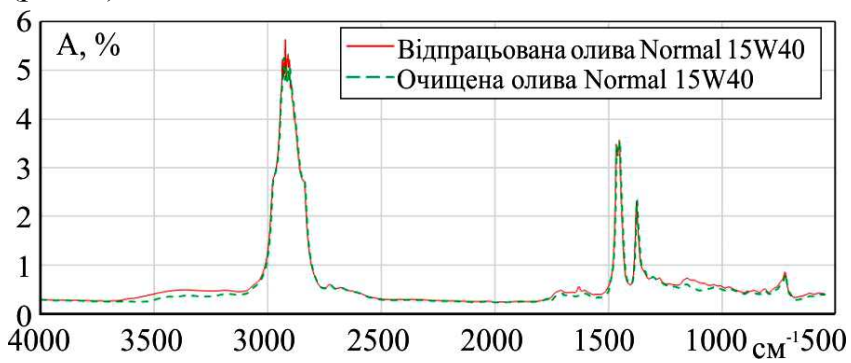

Рис. 6. ІЧ-спектри відпрацьованої та очищеної карбамідом мінеральної моторної оливи NORMAL 15W40

Отже, в очищених оливах відбувається зменшення значень КЧ, вмісту води, механічних домішок та зольності. Водночас, відбувається зростання значень в'язкісно-температурних властивостей. Однак, експлуатаційні властивості очищених у присутності карбаміду олив марок М-10ДМ та NORMAL 15W40 не відповідають значенням товарних олив, що потребує залучення додаткових методів доочищення. Використання кристалічного карбаміду, в процесі очищення ВММО, дає змогу зменшити вміст кисневмісних продуктів старіння, водночас, в очищеній оливі залишаються небажані поліциклічні ароматичні вуглеводні, АСР, продукти розкладу присадок та механічні домішки, для видалення яких необхідні додаткові стадії очищення.

\section{Висновки}

1. Встановлено принципову можливість очищення ВММО за допомогою кристалічного карбаміду. Суть розробленого методу полягає в коагуляції основної частини кисневмісних сполук, неорганічних компонентів і механічних домішок та подальшому їх відділенні разом із використаним карбамідом фільтруванням.

2. Встановлено, що за оптимальних умов проведення процесу (температура - 140 оС, тривалість - 80 хв, кількість карбаміду - $5 \%$ мас. на відпрацьовану оливу) можна одержати оливу, очищену від кисневмісних продуктів старіння, що підтверджено ІЧ-спектральним аналізом.

3. Основний ефект від використання карбаміду для очищення ВММО такий:

• збільшення кінематичної в'язкості олив на 0,49-7,34 \%; 
- збільшення IB олив на 2,27-5,45 \%;

- зниження кислотного числа олив на 71,42-88,19\%;

- зменшення вмісту механічних домішок на 28,20-37,10 \%;

- зниження зольності олив на 18,61-19,85 \%.

4. Цей метод може бути одним з етапів комбінованого процесу регенерації відпрацьованих мінеральних моторних олив.

\section{References}

1. Baatarhu, Ts., Gordienko, L. D., \& Nazarov, S. V. (2015). Vosstanovlenie kachestva otrabotannyih smazochnyih masel. Innovatsionnaya nauka: mezhdunarodnyiy nauchnyiy zhurnal, 12, 45-47. [In Russian].

2. Chervinskiy, T. I., Hrynyshyn, O. B., \& Korchak, B. O. (2015). Regeneratsiya vidpratsovanih motornih oliv u prisutnosti karbamidu. (Ser. Himiya, tehnologiya rechovin ta yih zastosuvannya). Bulletin of the National University of Lviv Polytechnic, 812, 158162. [In Ukrainian].

3. Compendium of recycling and destruction technologies for waste oils. Retrieved from: https://wedocs.unep.org/bitstre$\mathrm{am} /$ handle/20.500.11822/8601/IETC Waste Oils Compendium.pdf? sequence $=3$ \&isAllowed $=\mathrm{y}$

4. DSTU EN ISO 6245:2012. Naftoprodukty. Metod vyznachennia zoly. [In Ukrainian].

5. Guschin, V. A., Ostrikov, V. V., Guschina, A. I., \& Kalyuzhnyiy, S. V. (1997). Pat. 2078127 Rossiyskaya federatsiya, MPK S10M175/02. Sposob ochistki otrabotannogo masla. Zayavitel i patentoobladatel. № 4820906/04. - zayavl. 02.04.1990, opubl. 27.04.1997.

6. HOST 10577-78:2008. (2008). Nefteprodukty. Metod opredelenyia soderzhanyia mekhanycheskykh prymesei, from 01 Jan 1980. Moscow: Standartinform, 6 p. [In Russian].

7. HOST 2477-65: 2008-HOST 1044-41: 2008. (2008). Neft i nefteprodukty. Metod opredelenyia soderzhanyia vody, from 01 Jan 1966. Moscow: Yzd-vo standartov, 7 p. [In Russian].

8. HOST 33-2016: 2017. (2017). Neft i nefteprodukty. Opredelenyia kynematycheskoi i dynamycheskoi viazkosty, from 07 Jan 2017. Moscow: Yzd-vo standartov, 39 p. [In Russian].

9. HOST ISO 6618-2013. (2014). Nefteprodukty y smazochnyy materyaly. Opredelenye kyslotnoho y shchelochnoho chysla tytrovanyem s tsvetnym yndekatorom, from 01 Jan 2015. Moscow: Standartinform, 14 p. [In Russian].

10. Hrynyshyn, O., Korchak, B., et al. (2017). Change in properties of M-10DM mineral motor oil after its using in the diesel engine. Chemistry \& Chemical Technology, 11(3), 387-391. https://doi.org/10.23939/chcht11.03.387

11. Ivanova, L. V., et al. (2008). YK-spektrometryia v analyze nefty y nefteproduktov. Vestnyk Bashkyrskoho unyversyteta, 13(4), 869874. [In Russian].
12. Konferencyya Storon Stokgolmskoj konferencyy: Rukovodyashhye pryncypy po nayluchshym ymeyushhymsya metodam y ukazanyya po nayluchshym vydam pryrodooxrannoj deyatelnosty: Razdel VI Ukazanyya y rukovodyashhye pryncypy po kategoryyam ystochnykov: Kategoryy ystochnykov v Chasty III Prylozhenye S Kategoryya ystochnykov (m): Predpryyate po pererabotke otrabotannyx masel. Dakar, April 30 - May 4, 2007. (p. 6). [In Russian].

13. Korchak, B. O., Grynyshyn, O. B., \& Chervinskiy, T. I. (2017). Mineral engine oil composition and properties change after its operation. Scientific Bulletin of UNFU, 27(6), 93-97. https://doi.org/10.15421/40270619

14. Kucheryavyiy, V. I., \& Lebedev, V. V. (1970). Sintez i primenenie karbamida. Leningrad: Chemistry, 448 p. [In Russian].

15. Kulik, M. I. (2015). Utilizatsiya vidpratsovanih motornih mastil: ekologo-ekonomichniy aspekt. Lyudina ta dovkillya. Problemi neoekologiyi, 1-2, 122-128. [In Ukrainian].

16. Ofitsiyniy sayt kompaniyi Environmental XPRT. Retrieved from: https://www.environmental-expert.com/products/elvax-modellight-sdd-light-spectrometer-566889. [In Ukrainian].

17. Ostrikov, V. V., \& Busin, I. V. (2011). Ispolzovanie karbamida dlya ochistki motornyih masel. Tehnika $v$ selskom hozyaystve, 5 , 26-27. [In Russian].

18. Ostrikov, V. V., Popov, S. Yu., \& Zimin, A. G. (2014). Pat. 2528421 Rossiya, MPK S10M175/02. Sposob ochistki motornogo masla ot produktov stareniya i zagryazneniy. Zayavitel i patentoobladatel: - Gosudarstvennoe nauchnoe uchrezhdenie "Vserossiyskiy nauchno-issledovatelskiy institut ispolzovaniya tehniki i nefteproduktov Rossiyskoy akademii selskohozyaystvennyih nauk (GNU VNIITiN Rosselhozakademii). - \# 2013130794/04. zayavl. 04.07.2013, opubl. 20.09.2014.

19. Rudakova, N. Ya., et al. (1985). Karbamidnoe kompleksoobrazovanie nefti. Leningrad: Chemistry, 240 p. [In Russian].

20. Sokolov, A. I. (1976). Izmenenie kachestva masla i dolgovechnost avtomobilnyih dvigateley. Tomsk, 120 p. [In Russian].

21. Syeda Azeem Unnisa, \& Malek Hassanpour (2017). Development circumstances of four recycling industries (used motor oil, acidic sludge, plastic wastes and blown bitumen) in the world. Renewable and sustainable energy reviews, 72, 605-624. https://doi.org/10.1016/j.rser.2017.01.109

22. Tarasevich, B. N. (2012). IK spektryi osnovnyih klassov organicheskih soedineniy: spravochnyie materialyi. Moscow: Chemistry, 55 p. [In Russian].

23. Toltinova, L. A., Solyanov, A. N., Horoshev, S. V., \& Sirotina, V. V. (2005). Pat. 2246533 Rossiyskaya federatsiya, MPK S10M175/02. Sposob ochistki otrabotannogo masla. Zayavitel i patentoobladatel: Otkryitoe aktsionernoe obschestvo "Nauchnoissledovatelskiy tehnologicheskiy institut". - № 2002134870/04. - zayavl. 23.12.2002, opubl. 20.02.2005.

\section{B. O. Korchak, O. B. Hrynyshyn, T. I. Chervinskyy, N. M. Vytrykush, A. O. Nagurskyy, R. V. Ivashchenko \\ Lviv Polytechnic National University, Lviv, Ukraine}

\section{PURIFICATION OF THE USED MINERAL ENGINE OILS BY CRYSTALLINE CARBAMIDE}

Coagulation method is advisable to use in order to remove oxygen-containing products of aging from used oils and reduce their acidity number. Crystalline carbamide can be one of the easily accessible and perspective coagulants for the used mineral motor oils purification. Some oil purification methods known are those by using carbamide solutions (alcohol, often aqueous), but they lead to the entering additional quantities of water into the oil, to the formation of oil emulsion and promote foaming. Crystalline carbamide was added to the used oils and stirred at elevated temperature. The process efficiency was controlled by the oil acid number. The used carbamide together with the separated components of oil was filtered. Some factors influence on the purification process of used mineral motor M-10DM and NORMAL 15W40 oils by crystalline carbamide was studied. The optimal process conditions were established, namely: the amount of carbamide $-5 \%$ wt. on raw materials; temperature $-140{ }^{\circ} \mathrm{C}$; stirring time $-80 \mathrm{~min}$. The investigations of the purified mineral motor oils operational properties changes, using X-ray fluorescence and IR-spectral analysis standardized methods were carried out. It was found that number acidity recovered by carbamide used oils significantly reduced, which confirmed by IR spectral analysis. There is also a slight increase oil viscosity index, as well as a decrease of mechanical impurities and water. The ash content of the oils decreases too. This is also confirmed by the results of X-ray fluorescence analysis. We also found the feasibility of crystalline carbamide using for the used mineral engine oils purification in order to reduce the acid number. It was proved that during the used mineral engine oils purification by crystalline carbamide an oil emulsion does not form, which adversely affects the oil operating properties, unlike carbamide aqueous solutions. The crystalline carbamide application for the used mineral engine oils purification allows reducing the content of aging oxygen-containing products, while at the same time the unwanted polycyclic aromatic hydrocarbons, asphalt-resinous substances, additives decomposition products and mechanical impurities remain in the purified oil and to remove them is necessary to use additional purification stages.

Keywords: Oil recovery; IR-spectral; X-ray fluorescence; coagulation; acid number. 